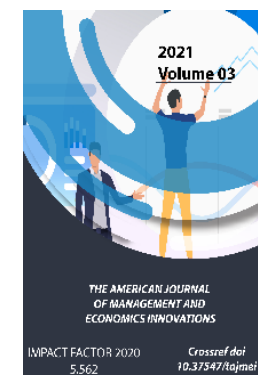

\title{
Economics And Management
}

\section{Ulugova Mokhira}

Tashkent Institute Of Irrigation And Agriculture Engineers Department Of Organization And Technology Of Water Resources Trainee Teacher, Uzbekistan

Journal Website:

http://theamericanjour nals.com/index.php/taj mei

Copyright: Original content from this work may be used under the terms of the creative commons attributes 4.0 licence.

\section{ABSTRACT}

Employees do not just perform in accordance with their own pay but also the pay of their peers. Pay inequality can act as a disincentive, reducing employee output and attendance by a significant amount. It is irrelevant whether they have a higher or lower salary than that of their co-workers. Pay disparity also lowers the ability of employees to work in their own interests and cooperate with other workers effectively. Pay inequality may have no discernible effect if an employee is aware that a peer with a higher salary produces a greater output than them.

\section{KEYWORDS}

Managerial economics, Pay, $\quad$ Employees $\quad$ Sberbank.

\section{INTRODUCTION}

Monetary incentives are an important aspect of managerial economics as they can be used to achieve particular business outcomes. Monetary incentives allow for a particular behaviour to appear more attractive to employees and contractors. An example of this is when an agent receives a bonus for reaching a key performance indicator. Providing this incentive allows the business to reach particular goals that would not otherwise be achieved.[46] Providing monetary incentives can also have to opposite effect, dissuading the agent from performing the incentivised behaviour. An example of this is when an agent is provided with a base salary independent of achieving a particular goal set by management. In this scenario there is no incentive for the agent to act in 
accordance the goal as they will receive their salary regardless.

Employees do not just perform in accordance with their own pay but also the pay of their peers. Pay inequality can act as a disincentive, reducing employee output and attendance by a significant amount. It is irrelevant whether they have a higher or lower salary than that of their co-workers. Pay disparity also lowers the ability of employees to work in their own interests and cooperate with other workers effectively. Pay inequality may have no discernible effect if an employee is aware that a peer with a higher salary produces a greater output than them.

Tournament theory is used to describe why different pay levels exist between different roles in the business hierarchy. The idea of tournament theory is that agents who put in effort to achieve promotions are rewarded with a higher, non-incremental, pay rate. The reward of a higher pay rate incentivises behaviour that leads to promotions. This behaviour is often lucrative and therefore ideal for the business. Tournaments can be very powerful at incentivising performance. Empirical research in economics and managements have shown that tournamentlike incentive structure increases the individual performance or workers and managers in the workplace.

Managerial economics to a certain degree is prescriptive in nature as it suggests a course of action to a managerial problem. Managerial economics aims to provide the tools and techniques to make informed decisions to maximise the profits and minimise the losses of a firm. Managerial economics has use in many different business applications, although the most common areas of its focus are in relation to the Risk, Pricing, Production and Capital decisions a manager makes.

The decision making steps, which are guided by the tools of managerial economics, include;

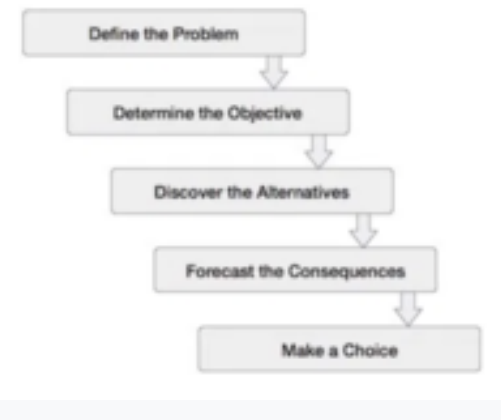

1. Define The problem

The first step in making a business decision is to understand the problem in its entirety. Without correct analysis on the problem at hand, developing a solution is an almost impossible task. Not correctly defining the problem can sometimes be the root of the problem that is trying to be solved.

\section{Determine the Objective}

The second step is evaluating the objective of the decision, or what the decision is trying to achieve. This step is determining a possible solution to the problem defined in step 1 . This step may provide multiple possible solutions to the problem previosly defined.

\section{Discover the Alternatives}

After in depth analysis into what is required to solve the problem faced by a business, options for potential solutions can be collated. In most cases, more than one possible solution to the problem exists. For example, a business striving to gain more attraction on 
social media could improve the quality of there content, collaborate with other creators or a combination of the two.

\section{Forecast the Consequences}

This step involves assessing the consequences of the problem solutions detailed in step 3 . Possible consequences of a business decisions could include; productivity, health, environmental impacts and risk. Here, managerial economics is used to determine the risks and potential financial consequences of an action.

\section{Make a Decision}

After the consequences and potential solutions to the problem at hand have been analysed, a decision can be made. At this point, the potential decisions should be measurable values which have been quantified by managerial economics to maximise profits, minimise risk and adverse outcomes of the firm.The make a decision step includes a sensitivity analysis of the solution. A sensitivity analysis of the selected sollution provides detail of how the output of the solution changes with changes to the inputs. The sensitivity analysis allows the strengths and weaknesses of the designed solution to be analysed.

\section{Managerial Economics Forces}

When making managerial decisions, managers use managerial economics to analyse the micro and macroeconomic environments. Microeconomics considers the actions of individual firms. In comparison, Macroeconomics is considers the actions and behaviour of the economy as a whole. Managerial economics studies how to analyse and compare alternative solutions to find the one most likely to achieve business goals. In this decision-making process, the role of managerial economics is to provide relevant analytical tools and analytical methods.

Forecasting and analysis of macroeconomic trends are essential in managerial economics. The macroeconomy focuses broadly on the principles of output, unemployment, political and social issues, inflation and other economic conditions.

These values play a large factor in managerial economics as they have the ability to provide an overview of global market conditions, which is imperative for managers to understand.

The political structure of a country, whether authoritarian or democratic; Political stability; and attitudes towards the private sector affect the growth and development of organization.

As can be seen from the information presented in Table 1, in 2018-2020 years, there was an upward trend in the amount of all types of retail loans granted by Sberbank to individuals. During this period, especially the amount of overdraft loans grew at a very high rate. This is evidenced by the fact that a lot of attention is paid by Sberbank to the practice of retail lending.

As can be seen from the information presented in Table 1, in the portfolio of retail loans of Sberbank, mortgage loans and consumer loans occupy a relatively high value. The impact of these loans was $56,1 \%$ and $33,4 \%$, respectively, in the case of 31 December 2020. This is explained by the increasing demand of the population for housing and consumer 
goods, as well as the growing number of their income.

An example of managerial economics using macroeconomic principles is a manager choosing to hire new staff rather than training old ones in a time where the rate of unemployment is high, as the possible talent pool would be very large.

The microeconomic consideration by managerial economics includes; consumer demand and supply, opportunity cost, revenue and cost. Microeconomics also gives indication on the most effective allocation of resources the business has available to it. These microeconomic theories and considerations are used via managerial economics to make decisions regarding the business. By understanding the principles of microeconomics, managers can be well informed to make accurate decisions regarding the form. An example of managerial economics using microeconomic principles is the decision of a manager to increase the price of the goods being sold. A manager should evaluate the price elasticity of the product to equate the respective demand of the product after the price change.

The Main Theories of Managerial Economics.

Microeconomics is the dominant focus behind managerial economics, some of the key aspects include;

\section{REFERENCES}

1. Ўзбекистон Республикаси Президентининг 2020 йил 12 майдаги ПФ5992-сонли "2020-2025 йилларга мўлжалланган Ўзбекистон Республикасининг банк тизимини ислох қилиш стратегияси тўғрисида"ги
фармони//ҚХММБ:06/205992/0581-сон. 13.05.2020 й.

2. Мордвинцева Н.В. Розничный банковский бизнес//Вестник ОГУ. Оренбург, 2010. - №13. - С. 185-189.

3. Буньковский А.В. Европейский опыт взаимодействия малого, среднего и крупного производственного предпринимательства//Известия. ᄀ Иркутск, 2011. - №3. - С. 77-81.

4. Исаков Н.Г., Никонец О.Е., Компаниец И.В., Кузнецова Н.А. Развитие розничного бизнеса коммерческого банка//Вестник Волжского университета имени В.Н. Татищева № 3, том 2, 2019. C. 170-178.

5. Синки Дж. Финансовый менеджмент в коммерческом банке и в индустрии финансовых услуг. Пер. с англ. - М.: Альпина Паблишер, 2017. - С. 611.-627.

6. Азимова Ш.С. Ўзбекистон тижорат банкларини кредит фаолиятини инновацион ривожлантиришни таъминлаш йўллари. И.ф.ф.А. дисс. Автореф. ᄀ- Тошкент, 2020. - Б. 47.

7. Годовой отчет Сбербанка по итогам 2020 года (C.42). www.cberbank.ru

8. Ўзбекистон Республикаси Президентининг 2020 йил 13 октябрдаги Пқ-4862-сонли “Ахолини тадбиркорликка жалб қилиш тизимини такомиллаштириш ва тадбиркорликни ривожлантиришга доир қўшимча чоратадбирлар тўғрисида"ги қарори//Қонун хужжатлари маълумотлари миллий базаси, 14.10.2020 й., 07/20/4862/1385сон; 27.03.2021 й., 07/21/5041/0244-сон. 